\title{
ERRATA
}

\section{ERRATUM TO: CHARACTERIZATION, LUMINESCENT \\ PROPERTIES, AND CRYSTAL STRUCTURE \\ DETERMINATION OF [Pt( $\operatorname{Ph}_{2}$ bipy $\left.) C_{2}\right]$}

\author{
S. Shamaei, A. Heidari, and V. Amani \\ Journal of Structural Chemistry, Vol. 57, No. 8, pp. 1675-1679, December, 2016
}

DOI: $10.1134 / \mathrm{S} 0022476617020305$

In the original publication S. Shamaei is marked as a corresponding author. In fact the corresponding authors are S. Shamaei and V. Amani. E-mail of V. Amani is v_amani2002@yahoo.com.

The online version of the original article can be found under doi: 10.1134/S0022476616080266. 